\title{
IN MEMORIAM
}

\author{
Проф. др Зоран Видојевић \\ (1940-2020)
}

\begin{abstract}
Становиште егзистениијалног тромостовља јесте да утопија, она конкретна, мора бити иманентна преображају стварности ка бољем, али и стварност тој врсти утопије, те да је солидарност која проистиче из аутономије човекове личности ... један од услова људског истргнућа из старог и новог примитивизма и варварства.
\end{abstract}

Зоран Видојевић, Тромостовље, понори и трептаји („Филип Вишњић“, Београд 2006, 19).

Овог пролећа, 22. маја 2020. године, изненада нас је напустио проф. др Зоран Видојевић, социолог, један од узорних посленика и великана из друштвено-хуманистичких наука у нас. Видојевић је од своје ране младости припадао социјалистичком покрету, а у идејнотеоријском погледу топлој струји неомарксистичке оријентације, која се залагала за дедогматизацију Марксове мисли, рехабилитацију теорије отуђења и ослобођења и афирмацију демократског социјализма са људским ликом. Он је настављач критичке социологије на трагу Мирослава Печујлића у нас и Имануела Волерстина у свету.

Зоран Видојевић је рођен 26. априла 1940. године у Мрчајевцима код Чачка. Основну школу завршио је у родном месту, гимназију у Чачку, а Правни факултет на Београдском универзитету. Докторирао је 1976. године на Одсеку за социологију Филозофског факултета Свеучилишта у Загребу, одбранивши дисертацију Класни корени неједнакости у савременом друштву, под менторством проф. др Ивана Кувачића.

У професионалној каријери, радио је, најпре, као истраживач и директор Марксистичког центра ЦК СКС, а од 1991. године као научни саветник у Центру за социолошка истраживања Института друштвених наука у Београду. Учествовао је у реализацији бројних научно-истраживачких пројеката у раду овог института, као и на бројним конференцијама у земљи и иностранству. Објавио је преко 200 библиографксих јединица, на српском и страним језицима, од чега 16 монографија, међу којима су најпознатије Самоуправљање - дело радничке класе, Драма једнопартијског система, објављене до 1990. године, а потом и Друштвени сукоби - од класних до ратних (1993), Транзиија, рестаурачија и неототалитаризащија (1997), Куда води глобализачија (2005), Демократија на заласку - ауторитарно-тоталитарна претьа (2010), Порази и алтернативе - претьа пустоши 
и етика отпора (2015). Такође, Видојевић је објавио и неколико запажених збирки песама, у кључу рефлексивно-медитативног лирског дискурса (Спокој и отпор, Биће, слика, звезде, Тромостовље, понори, mpenтаји). Оне откривају нов сензибилитет и књижевни идентитет аутора, али и његову онтолошко-антрополошку и егзистенцијалистичко-есенцијалну филозофију о теоријској узајамној вези одговорности и јединству: Ja - Други - Васељена, неопходности грађења синтезе философије, науке и уметности (свемир, мисли и љубави), панхуманистичких и трансхуманистичких мостова између човека и човечанства и других светова у свемиру.

У научном стваралаштву Зорана Видојевића видна је линија континуитета. У његовом фокусу су глобални проблеми савремености: од класних неједнакости, транзиције, глобализације, последица неолиберализма, актери социјалне динамике, до еколошких проблема, кризе демократије, кризе алтернативних пројеката, потребе грађења алтернативних стратегија одрживог развоја, хуманизације друштва и еманципације човека. У његовим студијама, критички се промишљају проблематика транзиције као комплексног и противречног друштвеног процеса на крају XX века, са неизвесним последицама по даљи развој светског друштва и човечанства. Аутор указује на противречности транзитног идентитета постсоцијалистичких друштава, на односе класних снага, раст сукоба између снага рада и снага капитала, на периферизацију ових друштава на Балкану, на неопходност критичког преиспитивања владајуће стратегије развоја и својеврсну „транзицију транзиције“, како се она не би свела на пуку неоколонијалну рестаурацију ових друштава.

У студији Куда води глобализащија, Видојевић је дао критику савременог неолибералног глобалног капитализма, трагајући и за одговором на питање Чему глобализащија?, указујући на њен социјални и еманципаторски потенцијал, за различитим типовима глобализације у савременој пракси. Он истиче разлику између нормативног и емпиријског модела глобализације, као и између асиметричне антагонистичке неолибералне глобализације, која је у функцији крупног капитала и реколонизације света и алтернативног асоцијативног социјалдемократског модела, који је у фунцкији јачања друштвене моћи и грађења света.

У студији Демократија на заласку, Видојевић се бави кризом владајућег облика демократије, а посебно на Западу, која се све више претвара у „демократију без народа“ (Диверже) и „колонијалну демократију“, чије су институције инструментализоване у служби крупног капитала и партократије лобистичких група. На делу су процеси „кварења демократије“, отуђења политике од грађана и подређивање законодавних институција отуђеним силама извршне власти, као и десуверенизације воље грађана и народа. Аутор указује на тоталитарне тенденције и претње по аутентичне вредности демократског поретка и путеве борбе за разотуђење политике у служби емнципаторских потреба грађанства и развоја друштва. 
Књига Порази и алтернативе - претьа пустоши и етика отnора представља круну Видојевићевих критичких истраживања савременог светског друштва и покушај грађења трансдисциплинарне синтезе у погледу на будућност човечанства. У њој се указује на поцепаност света, раст ирационалног насиља, неједнакости и противречности; на стање левице и других актера у ери глобализованог неолибералног капитализма, као и на кризу друштвено-хуманистичких наука, филозофије и значај изградње интегралне парадигме, теорије светскосистемске анализе и комплексне социологије (Е. Морен) за критичко истраживање савременог друштва и ново обликовање алтернативних пројеката борбе за одрживи развој хуманизацију друштва и еманципацију човека; за обнову прометејске социологије отпора и еманципације у савремености у служби „транзиције транзиције“, глобализације са људским ликом, редефинисања и обнове новог социјализма, на синтези слободе и једнакости социологије и екологије, напретка и хуманизма, глобалне правде и глобалног мира, панхуманизма и трансхуманизма. Јер, закључује Видојевић, човек није одговоран само за своју врсту, већ и за остатак света.

Видојевић у свом пледоајеу не нуди нову утопију, већ пише наговор за отрежњење и прометејско буђење, за промоцију етике отпора, побуне против сваког вида ропства. Он трага за реалним путевима изласка из кризе, алтернативни пројекат социјалдемократског развоја и управљања светом. Он актере види у бурдијеовском новом европском социјалном покрету, плуралистичкој коалицији нових актера: интелектуалног пролетеријата, маргинализованих нових генерација, у стратегији повезивања борбе за слободу и демократију са борбом за социјалну једнакост и достојанство, политичку и социјалну еманципацију. У овом контексту, наука и теорија, па и „социологија као борилачка дисциплина“" (П. Бурдије), морају се активно укључити као фактори борбене свести и демократског преображаја и избећи да буду у служби пуке репродукције и легитимизације садашње колонијалне свести и ,демократије без народа“.

Целокупним својим стваралаштвом, Зоран Видојевић је остао истраживач критичке неомарксистичке хуманистичке оријентације, човек усправног хода, велики хуманиста отвореног ума и срца, доследни левичар модерног израза, научник и књижевник чије ће дело тек изучавати нове генерације социолога и homo academicus-a.

Проф. Видојевић је активно сарађивао са бројним универзитетима, факултетима и научно-истраживачким институцијама у земљи и иностранству, посебно са Социолошким факултетом Универзитета Ломоносов, Институтом за социологију и Међународним центром за конфликтологију РАН у Москви. Био је предавач по позиву на бројним факултетима у Србији, Црној Гори, Македонији. Посебно је био активан у сарадњи са Одељењем за социологију и Институтом за социологију Филозофског факултета Универзитета у Нишу, у оквиру остваривања програма на магистарским и докторским студијама, на смеру Социологија друштвеног развоја, као и бројних научно-истраживачких пројеката, од 1986. године до смрти. У име бројних генера- 
ција студената и нишке заједнице социолога, искрено се захваљујем на свесрдној и коректној сарадњи у остваривању како истраживачких, тако и образовних циљева.

Зорановим одласком, научна заједница Србије изгубила је једног од највреднијих и најбољих социолога, научника и књижевника великог формата, хуманисту, протагонисту религије доброчинства и миротворца, градитеља мостова разумевања и солидарности. Међу југословенским и балканским народима, Видојевић је стално указивао на потребу регионалне сарадње, грађења мостова на овом простору, уместо даљих подела и сукоба. Као такав, био је један од оснивача часописа Балканске синтезе који се бави проблемима историје, културне и регионалне сарадње.

Поводом смрти Зорана Видојевића, у име истраживачког тима Традищија, модернизащија и идентитети у Србији и на Балкану, уредништва и програмског савета часописа Балканске синтезе и у своје лично име, Српском соичолошком друштву, научној и академској јавности Србије, изражавам искрено саучешће.

Својим ликом и делом, проф. др Зоран Видојевић ће остати да трајно живи у нама: његовој породици, колегама и колегиницама, студентима и пријатељима.

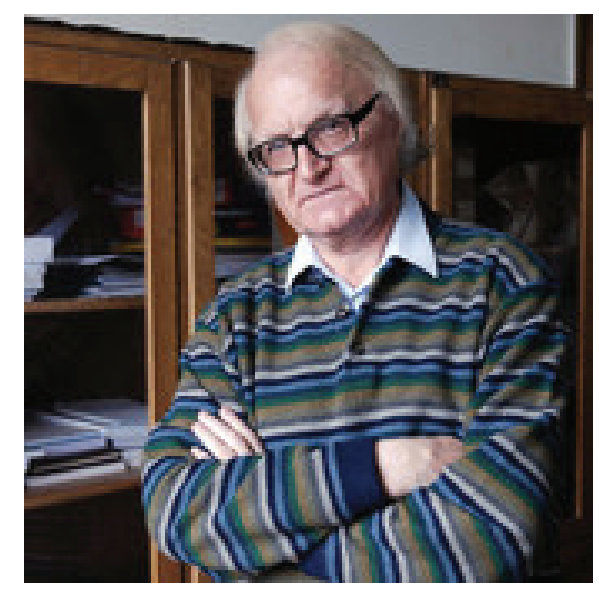

Проф. др Зоран Видојевић (1940-2020)

Др Љубиша Р. Митровић, професор емеритус 